\title{
Optimizing Dehydration of Apples Malus Domestica with Fructo-Oligosaccharide Incorporation
}

\author{
Mariana Buranelo Egea ${ }^{*}$, Rui Sérgio Souza Ferreira da Silva ${ }^{2}$, Fábio Yamashita ${ }^{2}$ and \\ Dionísio Borsato ${ }^{2}$ \\ ${ }^{1}$ Departamento de Engenharia Química; Universidade Federal do Paraná; C. P.: 19011; 81531-980; Curitiba - PR \\ - Brasil. ${ }^{2}$ Departamento de Ciência e Tecnologia de Alimentos; Universidade Estadual de Londrina; C.P.: 6001; \\ 86051-990; Londrina - PR - Brasil
}

\begin{abstract}
The objective of the present study was to study the effect of the variables of the osmotic dehydration process on sliced Fuji apples (Malus domestica) using a $2 \times 3^{2}$ factorial design. The variables studied in the apple slices were the pretreatment (blanching or acidification), the temperatures $\left(30,45\right.$ and $\left.60^{\circ} \mathrm{C}\right)$ and the FOS concentration $(40 \%$, $50 \%$ and $60 \% \mathrm{~m} / \mathrm{v}$ ) of the osmotic solution. There was no difference among the pretreatments for the water activity and titratable acidity. The slices pre-treated by the acidification presented less enzymatic browning (greatest luminosity $L^{*}$ value) combined with a greater soluble solid contents (thus, this treatment was selected). Treatments $T 4\left(45^{\circ} \mathrm{C}\right.$ and $\left.40 \% \mathrm{~m} / \mathrm{v}\right)$ and $\mathrm{T7}\left(60^{\circ} \mathrm{C}\right.$ and $\left.40 \% \mathrm{~m} / \mathrm{v}\right)$, using the acidification presented responses within the recommended standards and FOS were validated by the repetition.
\end{abstract}

Key words: surface response methodology, optimization, functional food, fructo-oligosaccharide

\section{INTRODUCTION}

Osmotic dehydration is the process of removing water by immersing the fruit and vegetables in a hypertonic solution (Lereci et al. 1985). Although it does not produce completely stable products, it is used as a pretreatment for the processes such as drying, freezing, chilling and pasteurization. Its main advantages are reduced losses of sensorial characteristics of the food accompanied by the texture improvement, increased pigment stability, modified sugar-organic acid ratio and reduced energy costs (Lewicki and Lukaszuk 2000, RauoltWack 1994). Use of the functional ingredients in this process is an alternative to aggregate the nutritional value or physiological functionality to the products.
In Brazil, as in many other countries, the fructooligosaccharides (FOS) are considered as ingredients and not food additives and, as in other countries, they are considered fibers source. Their ingestion may be associated to the flatulence, which is more obvious in lactose intolerant individuals. The harshness of this type of symptom is associated to the FOS dose consumed, that is, when the ingestion of a daily $20-30 \mathrm{~g}$ portion usually results in the onset of the discomfort, and the recommended doses are about $10 \mathrm{~g}$.day ${ }^{-1}$ (Búrigo et al. 2007, Hauly and Moscatto 2002, Mussatto and Mancilha 2007, Passos and Park 2003, Qiang et al. 2009).

Natural phenolic compounds in the fruits and vegetables in the presence of PPO and oxygen are oxidized to o-quinone that subsequently polymerizes nonenzymatically to brown pigments

*Author for correspondence: mariegea@1mferreira.com 
(Sapers 1993). This browning process leads also to a change in flavor and a reduction in the nutritional quality, especially ascorbic acid loss. The most important factors that determine the rate of fruit and vegetable enzymatic browning are the concentrations of active PPO and phenolic compounds, $\mathrm{pH}$, temperature, and oxygen availability in the tissue. Oxygen and $\mathrm{pH}$ also influence subsequent nonenzymatic browning (Martinez and Whitaker 1995).

PPO is not a heat resistant enzyme, and therefore, heat treatment between 70 and $90^{\circ} \mathrm{C}$ for a short period is sufficient to inactivate it and prevent undesirable reactions in the product (Chutintrasri and Noomhorm 2006). This process is much used as the pretreatment for canning, freezing and dehydration. The optimum $\mathrm{pH}$ of this enzyme is a between 6 and 7, and it is inactivated at $\mathrm{pH}$ below 4 (Araújo 2004, Haminiuk et al. 2005).

The blanching pretreatment on the osmotic dehydration has been used to decrease substantially the metabolic structural changes in the carrots in long-term storage (Escobar et al. 2007). Borin et al. (2008) used blanching before the osmotic dehydration and found increased acceptance of the product after drying, since the sensory analysis of non-blanched pumpkins $(C$. moschata) osmotically dehydrated with sucrose and sodium chloride showed rejection of the taste of the raw vegetable by some tasters. Moreover, the blanching pretreatment before osmotic dehydration of under investigated conditions proved to increase the solid gain in comparison with the samples without pretreatment and were characterized by higher water loss when compared with frozen fruit (Kowalska et al. 2008).

Matusek et al. (2008) studied the osmotic dehydration process in apple cubes at concentrations of 40,50 and $60 \%$ sucrose or FOS, at 40,50 and $60^{\circ} \mathrm{C}$ for 20,30 and 40 minutes. The moisture content, water and mass loss and solid gain were influenced by the temperature, time, concentration and type of osmotic agent. The authors concluded that these ingredients could be used for fruit osmotic dehydration, but because of the FOS molecular size, there was less diffusion compared to sucrose. Water loss with FOS was lower compared to sucrose. However, at higher temperatures and concentrations in the osmotic process, water loss was greater in the solutions with FOS than with sucrose.

According to Rastogi et al. (2002), the parameters that influence the weight loss and solid gain could be summarized as osmotic solution concentration and temperature, agitation, food to osmotic solution ratio, food structure (porosity, etc.), shape and size (which determined the surface area and resistance for mass transfer in the form and thickness), nature and molecular weight of the osmotic solute and pressure (high pressure, ambient or vacuum).

Response surface methodologies (RSM) can be used in order to improve the quality of osmotic dehydrated products by optimizing the processing variables. The RSM provide a relatively smaller number of experiments and the study of several variables at the same time as, for example, osmotic solution concentration, temperature, time and agitation of the osmotic process (Abud-Archila et al. 2008, Fernandes et al. 2006, Ozdemir et al. 2008, Uddin et al. 2004, Vega-Gálvez et al. 2007). The objective of the present study was to investigate the effect of the variables of the osmotic dehydration process (pretreatments of apple slices, osmotic solution temperature and FOS concentration) in apple (Malus domestica) slices using a factorial design and response surface analysis.

\section{MATERIAL AND METHODS}

Fruits from three apple cultivars (Fuji, Red Golden and Gala) were purchased from the local market in Londrina, PR, Brazil and stored in plastic bags at $5^{\circ} \mathrm{C}$ until processing.

The ingredient used as solute in the osmotic dehydration was Beneo Orafti ${ }^{\circledR}$ P95, containing 93.2\% fructo-oligosaccharide and $6.8 \%$ de glucose, fructose and sucrose, according to the manufacturer.

A $2 \times 3^{2}$ factorial design was used with one repetition at the central point, with one qualitative and two quantitative variables, totaling 20 experiments. The factors were pretreatments for enzymatic inactivation (blanching or acidification), solution temperature (30, 45 and $60^{\circ} \mathrm{C}$ ) and fructo-oligosaccharide concentration in the solution $(40,50$ and $60 \% \mathrm{~m} / \mathrm{v})$ (Table 1).

The fruits were washed with neutral detergent, disinfected in a hypochlorite solution (Carnelossi et al. 2005) and cut in the slices approximately 5 $\mathrm{mm}$ thick in the horizontal direction (transversal to the axis) without removing the peel (for the transference of radial mass to the plate). The seeds were removed with the core using a coconut perforator. 
Table $1-2 \times 3^{2}$ factorial design for osmotic dehydration of apple slices and physical chemical properties of osmotically dehydrated apple slices.

\begin{tabular}{|c|c|c|c|c|c|c|c|c|c|c|}
\hline \multirow[b]{2}{*}{$\mathbf{E}$} & \multicolumn{3}{|c|}{$\begin{array}{c}\text { Codified } \\
\text { variables }\end{array}$} & \multicolumn{3}{|c|}{ Original variables } & Moisture & $\begin{array}{c}\text { Soluble solid } \\
\text { contentes ( }{ }^{\circ} \text { Brix) }\end{array}$ & \multirow{2}{*}{$\begin{array}{c}\mathbf{A w} \\
0.980 \pm 0.00\end{array}$} & \multirow{2}{*}{$\begin{array}{c}\begin{array}{r}{ }^{\mathbf{o}} \text { Brix/ } \\
\text { acidity }\end{array} \\
12.50\end{array}$} \\
\hline & $\mathrm{x}_{1}$ & $\mathrm{x}_{2}$ & $\mathrm{Z}$ & $\mathrm{T}^{1}$ & {$[\mathrm{FOS}]^{2}$} & $\mathrm{PT}$ & In natura $85.44 \pm 0.42$ & $13.03 \pm 0.00$ & & \\
\hline 1 & -1 & -1 & 2 & 30 & 40 & A & $74.29 \pm 2.10$ & $33.31 \pm 1.06$ & $0.978 \pm 0.00$ & 11.31 \\
\hline 2 & -1 & 0 & 2 & 30 & 50 & $\mathrm{~A}$ & $66.51 \pm 1.60$ & $44.06 \pm 0.25$ & $0.971 \pm 0.00$ & 31.66 \\
\hline 3 & -1 & +1 & 2 & 30 & 60 & A & $60.02 \pm 4.77$ & $41.89 \pm 1.75$ & $0.961 \pm 0.00$ & 28.20 \\
\hline 4 & 0 & -1 & 2 & 45 & 40 & $\mathrm{~A}$ & $72.24 \pm 3.19$ & $31.07 \pm 0.76$ & $0.976 \pm 0.00$ & 28.12 \\
\hline 5 & 0 & 0 & 2 & 45 & 50 & A & $61.51 \pm 1.87$ & $38.65 \pm 0.76$ & $0.964 \pm 0.00$ & 29.96 \\
\hline 6 & 0 & +1 & 2 & 45 & 60 & A & $56.43 \pm 2.58$ & $43.14 \pm 0.71$ & $0.949 \pm 0.00$ & 20.95 \\
\hline 7 & +1 & -1 & 2 & 60 & 40 & A & $62.52 \pm 0.56$ & $34.65 \pm 1.06$ & $0.972 \pm 0.00$ & 32.48 \\
\hline 8 & +1 & 0 & 2 & 60 & 50 & A & $50.15 \pm 1.80$ & $48.30 \pm 0.60$ & $0.942 \pm 0.00$ & 45.22 \\
\hline 9 & +1 & +1 & 2 & 60 & 60 & A & $43.53 \pm 0.47$ & $55.74 \pm 0.61$ & $0.930 \pm 0.01$ & 39.49 \\
\hline 10 & 0 & 0 & 2 & 45 & 50 & A & $63.55 \pm 3.32$ & $38.56 \pm 0.50$ & $0.967 \pm 0.00$ & 25.38 \\
\hline 11 & -1 & -1 & -2 & 30 & 40 & B & $66.32 \pm 0.84$ & $31.00 \pm 0.50$ & $0.981 \pm 0.00$ & 50.90 \\
\hline 12 & -1 & 0 & -2 & 30 & 50 & B & $56.11 \pm 1.19$ & $40.07 \pm 0.76$ & $0.960 \pm 0.00$ & 58.23 \\
\hline 13 & -1 & +1 & -2 & 30 & 60 & B & $56.38 \pm 2.35$ & $42.23 \pm 0.76$ & $0.963 \pm 0.00$ & 72.35 \\
\hline 14 & 0 & -1 & -2 & 45 & 40 & B & $63.59 \pm 1.54$ & $35.14 \pm 0.00$ & $0.977 \pm 0.00$ & 88.56 \\
\hline 15 & 0 & 0 & -2 & 45 & 50 & B & $59.14 \pm 0.54$ & $41.14 \pm 2.08$ & $0.980 \pm 0.00$ & 94.93 \\
\hline 16 & 0 & +1 & -2 & 45 & 60 & B & $50.67 \pm 3.05$ & $46.89 \pm 4.48$ & $0.943 \pm 0.00$ & 84.33 \\
\hline 17 & +1 & -1 & -2 & 60 & 40 & B & $59.58 \pm 0.43$ & $39.31 \pm 1.61$ & $0.979 \pm 0.00$ & 72.47 \\
\hline 18 & +1 & 0 & -2 & 60 & 50 & B & $49.41 \pm 4.16$ & $46.47 \pm 0.58$ & $0.962 \pm 0.00$ & 70.40 \\
\hline 19 & +1 & +1 & -2 & 60 & 60 & B & $45.88 \pm 1.51$ & $53.94 \pm 1.04$ & $0.937 \pm 0.01$ & 75.02 \\
\hline 20 & 0 & 0 & -2 & 45 & 50 & B & $59.32 \pm 1.69$ & $39.81 \pm 1.44$ & $0.973 \pm 0.00$ & 80.80 \\
\hline
\end{tabular}

$\mathrm{E}=$ experiment; $\mathrm{PT}=$ pretreatments, $\mathrm{A}=$ acidification, $\mathrm{B}=$ blanching, $\mathrm{Aw}=$ water activity.

'Osmotic solution temperature $\left({ }^{\circ} \mathrm{C}\right)$.

${ }^{2}$ FOS concentration in the osmotic solution $(\% \mathrm{~m} / \mathrm{v})$.

The following pretreatments were used for the enzymatic inactivation of the apple slices:

a) Blanching by immersing the apple slices in water at $70^{\circ} \mathrm{C}$ for three minutes and cooling in a water bath at room temperature for five minutes (Haminiuk et al. 2005);

b) Acidification by immersing the apple slices in $1 \%(\mathrm{~m} / \mathrm{v})$ citric acid solution at room temperature for 15 minutes (Matusek et al., 2008).

The fruit:solution ratio in the osmotic dehydration was $1: 10 \mathrm{~m} / \mathrm{v}$ (Dionello et al. 2007, Elias et al. 2008, Matusek et al. 2008). After the process, the solution excess on the surface of the slices was removed with paper towel (Matusek et al., 2008). The soluble solid contents, moisture, titratable acidity and acidity in the organic acid (malic acid), $\mathrm{pH}$, proteins, ash and total solids were determined according to the analytical norms of the AOAC (1994). Water activity was determined in AQUALAB equipment, model $\mathrm{Cx}-2$ (Decagon), at $25^{\circ} \mathrm{C}$. The color of the samples was determined the CIELAB system parameters $L^{*}, a^{*}$ and $b^{*}$, where $\mathrm{L}^{*}$ defines the luminosity $\left(\mathrm{L}^{*}=0\right.$ black and $\mathrm{L}^{*}=$ 100 white) and $\mathrm{a}^{*}$ and $\mathrm{b}^{*}$ determine the chromaticity $\left(+a^{*}=\right.$ red and $-a^{*}=$ green, $+b^{*}=$ yellow and $-b^{*}=$ blue). The cylindrical coordinates $\mathrm{H}^{*}$ and $\mathrm{C}^{*}$ from equations 1 and 2, respectively (Hunterlab 1996), where $C^{*}$ defines the chromaticity (color intensity, the chrome values close to zero determine neutral colors and those nearer to sixty determine vivid colors), and $\mathrm{H}^{*}$ is the tone, zero $=$ red, $90=$ yellow, $180=$ green and $270=$ blue).

$$
\begin{aligned}
& \mathrm{H}^{*}=\arctan \left(\frac{\mathrm{b}^{*}}{\mathrm{a} *}\right) \\
& \mathrm{C}^{*}=\sqrt{\mathrm{a}^{* 2}+\mathrm{b}^{* 2}}
\end{aligned}
$$

The analyses were carried out in triplicate with the samples before and after the osmotic dehydration, except for the color analysis where six repetitions were carried out.

The water loss (WL) and solid gain (SG) were estimated according to equations 3 and 4 (Sharma et al. 2000):

$$
W L=100\left(\frac{x_{0}-x_{t}}{M_{0}}\right)
$$

where: $\mathrm{WL}=$ percentage of water loss compared to the initial mass $(\%), \mathrm{x}_{0}=$ initial water mass in 
the product $(\mathrm{g}), \mathrm{x}_{\mathrm{t}}=$ water mass in the product at time $\mathrm{t}(\mathrm{g}), \mathrm{M}_{0}=$ initial product mass $(\mathrm{g})$

$$
S G=\left(\frac{M s_{t}-M s_{0}}{M_{0}}\right)
$$

where: $\mathrm{SG}=$ solids percentage gain compared to initial product mass, $\mathrm{Ms}_{0}=$ initial dry mass $(\mathrm{g})$, $\mathrm{Ms}_{\mathrm{t}}=$ dry mass at time $\mathrm{t}(\mathrm{g}), \mathrm{M}_{0}=$ product mass at initial time $(\mathrm{g})$.

The statistical analysis was carried out by the Statistica ${ }^{\circledR} 7.0$ software including the parameter estimation and analyses of variance for multiple linear regressions at a 5\% level of significance. In this design, the main effects and the interactions among the variables could be calculated.

\section{RESULTS AND DISCUSSION}

The analyses of the raw material are shown in Table 2. These characteristics were used to choose the apple cultivar for osmotic dehydration. The Fuji apple presented the highest moisture content and lowest soluble solid contents. This cultivar had the lowest annual average price ( $\mathrm{R} \$ 1.56$ per kilogram), was easily available in the market (81.3\%) (Cetnarski Filho et al. 2008) and was, therefore, selected for the study.

Table 2 - Physical chemical analyses of the in natura apple cultivars.

\begin{tabular}{cccc}
\hline & \multicolumn{3}{c}{ Apple Cv. } \\
\cline { 2 - 4 } & Fuji & Gala & Red Golden \\
\hline Moisture (\%) & $86.22 \pm 0.18$ & $84.76 \pm 0.13$ & $82.39 \pm 0.20$ \\
Proteins (\%) & $0.20 \pm 0.07$ & $0.16 \pm 0.02$ & $0.20 \pm 0.07$ \\
Ash (\%) & $0.33 \pm 0.07$ & $0.53 \pm 0.04$ & $0.48 \pm 0.03$ \\
Total solids (\%) & 13.78 & 15.24 & 17.61 \\
Soluble solid contents ( ${ }^{\circ}$ Brix) & $12.4 \pm 0.24$ & $14.69 \pm 0.50$ & $16.14 \pm 1.06$ \\
Water activity & $0.980 \pm 0.00$ & $0.980 \pm 0.00$ & $0.975 \pm 0.00$ \\
Titratable acidity (mL/100g) & $1.83 \pm 0.16$ & $3.27 \pm 0.08$ & $2.20 \pm 0.22$ \\
Acidity (malic acid) (g/100g) & 0.12 & 0.22 & 0.15 \\
\hline
\end{tabular}

The most abundant organic acid in apple is malic acid. The Golden Delicious variety after 35 days of storage at $8^{\circ} \mathrm{C}$ presented $16^{\circ} \mathrm{Brix}$ (TSS content) and approximately $0.35 \%$ malic acid content (Salas et al. 2011). Feliciano et al. (2010) characterized the Portuguese apple varieties and found that the malic acid content ranged from 137 to $425 \mathrm{mg} / 100 \mathrm{~g}$ edible portion and moisture content from 78 to $84 \mathrm{~g} / 100 \mathrm{~g}$ edible portion. In the varieties from central Macedonia, soluble solids levels were found ranging from 11.3 to 14.7\% (Drogoudi and Pantelides, 2011).

Córdova (2006) carried out physical chemical characterization of in natura apple slices and obtained values of $87.20 \%, 0.24 \%$ and $0.30 \%$ for the moisture, ash and proteins, respectively. These values were close to those detected in the present study considering that the raw material of plant origin was highly heterogeneous because of the degree of ripeness, harvest and planting periods, crop management and storage conditions. The values reported by Córdova (2006) for titratable acidity and total soluble solids were $0.22 \mathrm{~g} / 100 \mathrm{~g}$ and $14.9^{\circ}$ Brix and were higher than those obtained in the present study, probably due to different maturity stages that were not considered in this study.

Table 1 shows the results for the analyses of moisture, soluble solids, water activity and obrix/acidity for the osmotic dehydration experiments performed. The color parameters and the water loss and solid gain calculations are shown in Table 3 . The acidity responses for the organic acid, total solids (data not shown) and the $\mathrm{H}^{*}$ and $\mathrm{C}^{*}$ parameters were calculated from the experimental data obtained. The standard deviations followed the experimental values. Figure 1 shows the moisture content of the apple slices after the osmotic dehydration, submitted to the acidification (A) and blanching (B) pretreatments, respectively.

The model proposed to describe the moisture content performance in the osmotically dehydrated apple slices, using the experimental design, is shown by equation 5 , where the variables are codified.

$$
\begin{aligned}
& \text { Moisture }=58.2-5.7 \cdot \mathrm{T}+1.4 \cdot \mathrm{T}^{2}-7.4 \cdot \mathrm{C}- \\
& 2.2 \cdot \mathrm{PT}-1.4 \cdot \mathrm{T} \cdot \mathrm{C}+1.8 \cdot \mathrm{T} \cdot \mathrm{PT}+1.2 \cdot \mathrm{C} \cdot \mathrm{PT} \\
& \mathrm{R}^{2}=0.97
\end{aligned}
$$


where moisture is given in $\%, \mathrm{~T}$ is the osmotic dehydration temperature, $\mathrm{C}$ is the FOS concentration and PT the pretreatment to which the apple slices were submitted.

Table 3 - Color parameters of osmotically dehydrated fruits.

\begin{tabular}{|c|c|c|c|c|}
\hline $\mathbf{E}$ & $\mathbf{L}^{*}$ & $\mathbf{H}^{*}$ & Water loss $(\%)$ & Solid gain (\%) \\
\hline In natura & $71.91 \pm 1.84$ & 1.55 & Water loss (\%) & Solid gain $(\%)$ \\
\hline 1 & $67,32 \pm 1,10$ & 1,43 & 4.50 & 7.41 \\
\hline 2 & $68.44 \pm 2.86$ & 1.45 & 6.95 & 11.39 \\
\hline 3 & $66.77 \pm 6.45$ & 1.44 & 9.17 & 10.58 \\
\hline 4 & $60.31 \pm 6.77$ & 1.41 & 4.68 & 6.58 \\
\hline 5 & $67.51 \pm 4.17$ & 1.42 & 8.83 & 9.38 \\
\hline 6 & $69.74 \pm 2.91$ & 1.48 & 10.63 & 11.05 \\
\hline 7 & $63.05 \pm 5.21$ & 1.34 & 8.44 & 7.9 \\
\hline 8 & $68.10 \pm 5.16$ & 1.44 & 13.01 & 12.96 \\
\hline 9 & $70.25 \pm 2.52$ & 1.39 & 15.86 & 15.71 \\
\hline 10 & $66.91 \pm 3.76$ & 1.36 & 8.07 & 9.35 \\
\hline 11 & $53.15 \pm 4.97$ & 1.35 & 7.92 & 7.50 \\
\hline 12 & $47.31 \pm 1.55$ & 1.18 & 12.18 & 11.09 \\
\hline 13 & $58.05 \pm 4.12$ & 1.42 & 11.94 & 11.98 \\
\hline 14 & $59.45 \pm 2.63$ & 1.42 & 9.05 & 9.05 \\
\hline 15 & $64.48 \pm 2.49$ & 1.41 & 10.90 & 11.54 \\
\hline 16 & $61.79 \pm 3.29$ & 1.33 & 14.39 & 13.92 \\
\hline 17 & $61.64 \pm 2.74$ & 1.40 & 10.73 & 10.78 \\
\hline 18 & $60.84 \pm 4.22$ & 1.34 & 14.99 & 13.74 \\
\hline 19 & $59.36 \pm 0.98$ & 1.32 & 16.41 & 16.84 \\
\hline 20 & $57.41 \pm 4.97$ & 1.31 & 10.86 & 10.98 \\
\hline
\end{tabular}

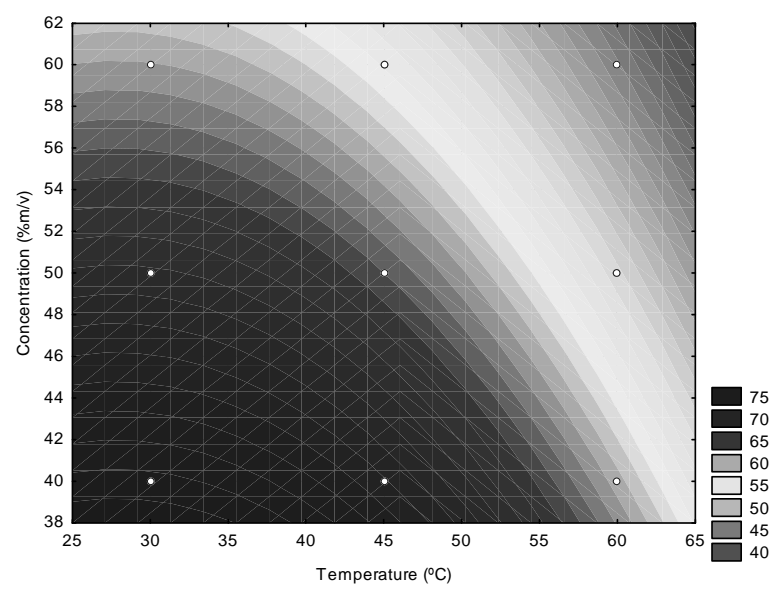

(A)

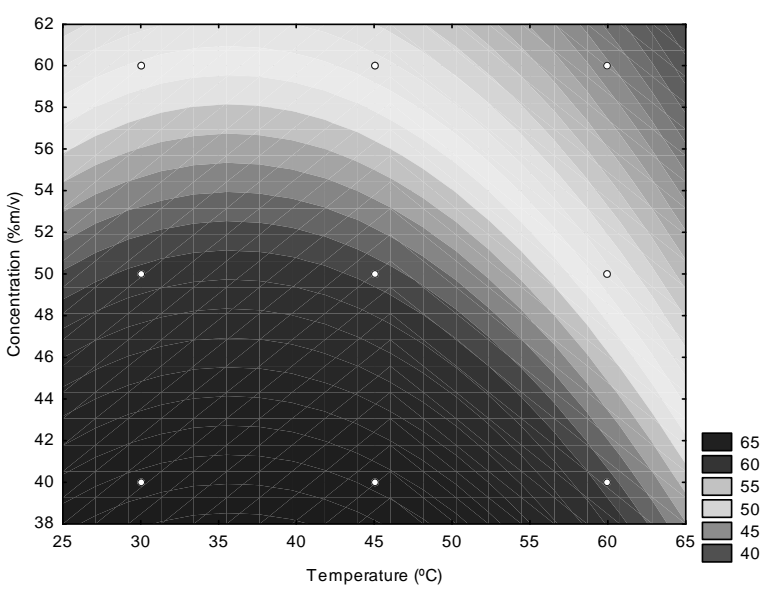

(B)

Figure 1 - Moisture contents of osmotically dehydrated apple slices in the acidification (A) and blanching (B) pretreatments, respectively, in function of temperature and fructooligosaccharides concentration.

In the model, the FOS concentration was the variable with greatest effect on the moisture, followed by the temperature and pretreatment. The effect of temperature and solution concentration was negative, indicating moisture decreasing with increasing the temperature and FOS concentration in the osmotic solution. The increase of FOS concentration results in a large difference of osmotic pressure between the product and the osmotic solution, enhancing the water diffusion (Sousa et al. 2003).

The blanching pretreatment was negative when the osmotic dehydration was used and decreased moisture in the apple slices submitted to osmotic dehydration. According to Matusek et al. (2008), the blanching makes the plant tissue membranes 
more permeable to the mobility of the solids involved in osmotic dehydration.

Moreno et al. (2000) studied the osmotic dehydration of strawberries blanched with steam and noted that the mass transfer process increased when it was applied prior to osmotic dehydration. This indicated that the changes in the tissue induced by blanching, such as cell decompartmentation, led to a faster mass transfer rate, even by hydrodynamic mechanism.

The water activity $\left(\mathrm{a}_{\mathrm{w}}\right)$ of the dehydrated products ranged from 0.93 to 0.98 , but none of the variables studied (temperature, solution concentration and pretreatment) presented a significant effect. Generally, the osmotic dehydration is not used as a single treatment, because after the process the products $a_{w}$ do not ensure the physical, chemical and microbiological stability. Thus, other conservation methods are needed to complement this technique, to reduce the $\mathrm{a}_{\mathrm{w}}$ to a value that

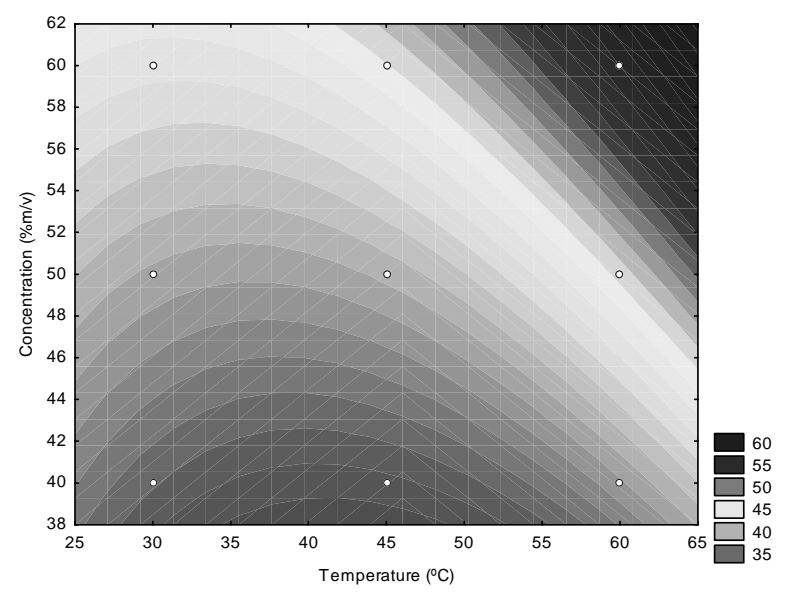

(A) guarantees the stability during the storage as reported by several authors (Buchweitz 2005, Pereira et al. 2003, Valente 2007).

The soluble solid content of the osmotically dehydrated samples increased compared to the in natura sample, indicating that there was impregnation and/or incorporation of the solids present in the osmotic solution. This increase was influenced by the osmotic solution temperature and FOS concentration. Paes et al. (2008) reported that as the temperature of the osmotic dehydration solution increased, the soluble solid content also increased in Fuji apples. For $10{ }^{\circ} \mathrm{C}$, the final soluble solids content was $23{ }^{\circ}$ Brix whereas the maximum soluble solid content was found in the process performed at $50{ }^{\circ} \mathrm{C}\left(32.5^{\circ} \mathrm{Brix}\right)$.

Figure 2 shows the soluble solids content after osmotic dehydration of the apple slices in the acidification (2A) and blanching pretreatments.

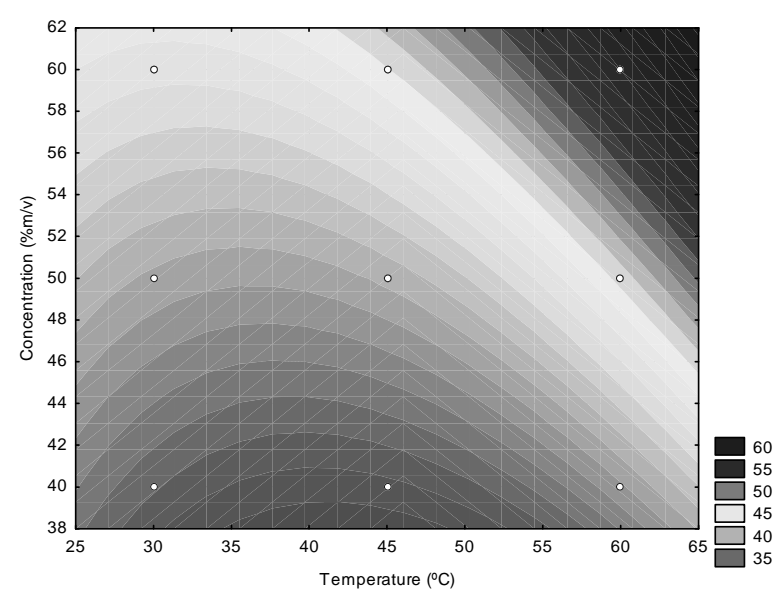

(B)

Figure 2 - Soluble solid content of the osmotically dehydrated apple slices in the acidification (A) and blanching (B) pretreatments in function of temperature and fructo-oligosaccharide concentration.

The model proposed to describe the performance of the soluble solid content in the osmotically dehydrated apple slices, using an experimental design, is represented by equation 6 , with coded variables.

$T S S=41.5+3.8 \cdot T-1.6 \cdot T^{2}+6.6 \cdot C+2.0 \cdot T \cdot C$

$\mathrm{R}^{2}=0.90$,

where TSS is the soluble solid content ( $\left.{ }^{\circ} \mathrm{Brix}\right), \mathrm{T}$ is the dehydration temperature and $\mathrm{C}$ is the FOS concentration in the osmotic process.

This model fitted the experimental data well $\left(\mathrm{R}^{2}=\right.$ 0.90 ), shown by the non-significant lack of fit at the level of $5 \%$. The osmotic solution concentration was the variable that had greatest effect for the incorporation of soluble solids, while the blanching or acidification pretreatments were not significant, and therefore, were not presented in the model.

Among the variables studied, only the pretreatment influenced the titratable acidity of the dehydrated slices. The same occurred with the acidity in malic acid that increased in the osmotically dehydrated apple slices submitted to the acidification pretreatment (data not shown). 
The color parameters, $\mathrm{L}^{*}$ and $\mathrm{H}^{*}$, of the apple slices after the osmotic dehydration were only influenced by the pretreatments. The acidification increased luminosity $\left(\mathrm{L}^{*}\right)$ and blanching decreased the $L^{*}$ value (Table 4). Figure 3 shows the performance of the osmotically dehydrated apple slices with the acidification (A) and blanching (B) pretreatments. In Figure $3 \mathrm{~A}$, the highest FOS concentration level and the use of the central point of the process temperature were responsible for the optimum luminosity region indicated by its higher value for the acidification pretreatment. In Figure $3 \mathrm{~B}$, the highest luminosity value for apple slices pretreated by the blanching started at the midpoint

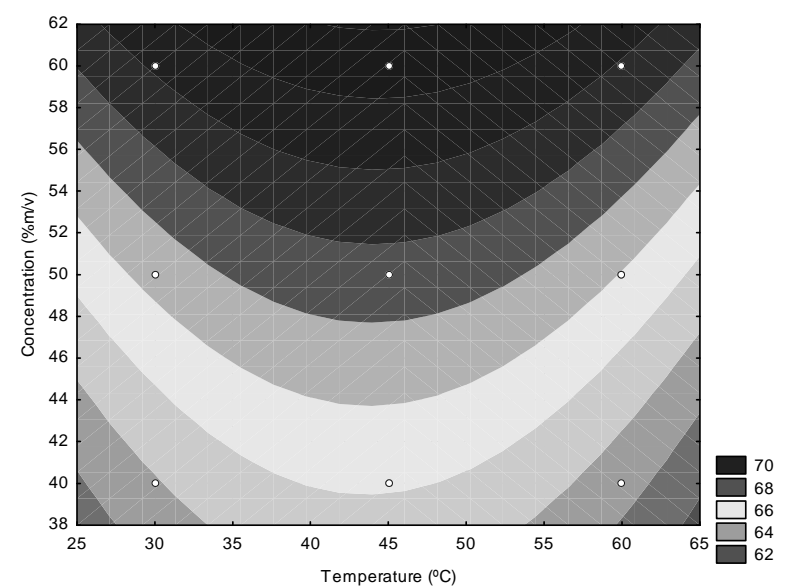

(A) of the temperature and at any level studied of FOS concentration. Therefore, the acidification was not only simple to perform compared to the osmotic dehydration but also preserved better the raw material quality, and could be less expensive on an industrial scale. All the treatments carried out presented lower mean $\mathrm{L}^{*}$ values than the fruit in natura, indicating that the osmotic dehydration decreased this value, and similar results were obtained by Córdova (2006). This change was justified by the development of enzymatic browning in the fruit. Furthermore, dehydration generally reduced the $\mathrm{L}^{*}$ value (Demczuk Junior et al. 2008).

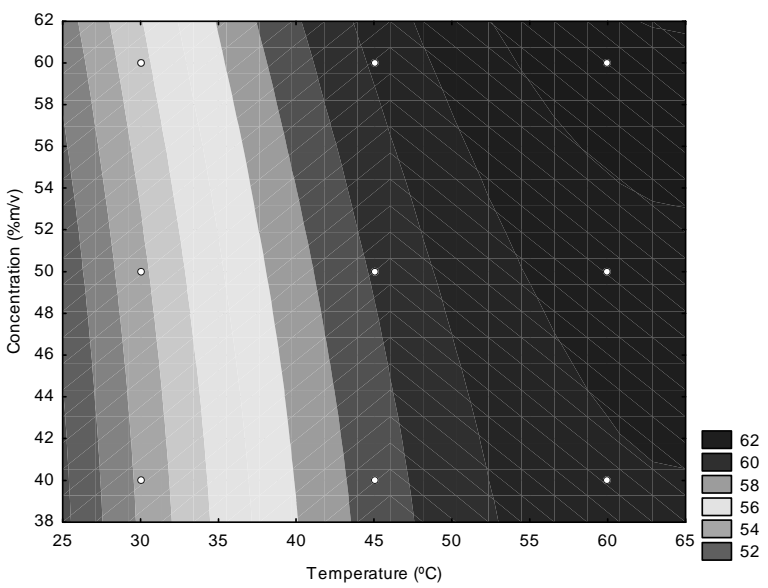

(B)

Figure 3 - Luminosity parameter ( $\left.\mathrm{L}^{*}\right)$ of the osmotically dehydrated apple slices in the acidification (A) and blanching (B) pretreatments in function of temperature and fructo-oligosaccharide concentration.

The color parameters $a^{*}, b^{*}$ and $C^{*}$ were not influenced by the variables of the dehydration process (data not shown). Compared to the initial sample, it was observed that both the pretreatments (acidification or blanching) increased the $a^{*}$ parameter, initially close to zero, suggesting enzymatic browning. The chrome tonality performed similarly to the $\mathrm{b}^{*}$ parameter and was, therefore, the most expressive factor in defining a fruit color and could be verified by the higher values of the $b^{*}$ parameter compared to the $a^{*}$ parameter and yellow was the predominant color. The chrome behavior was reported by Córdova (2006) where there was an increase in $C^{*}$ after osmotic dehydration with sucrose which further increased after drying.

Figures 4A and 4B show the water loss performance of the apple slices after osmotic dehydration, submitted to the acidification and blanching pretreatments, respectively.

The model fitted the water loss experimental data well (equation 7), with $\mathrm{R}^{2}=0.95$ and nonsignificant lack of fit.

$$
\begin{aligned}
& P A=10.5+2.2 \cdot T-0.6 \cdot T^{2}+2.8 \cdot C+1.5 \cdot P T \\
& -0.6 \cdot T \cdot P T \\
& \mathrm{R}^{2}=0.95
\end{aligned}
$$

where $\mathrm{PA}$ is the water loss (\%), T the dehydration temperature, $\mathrm{C}$ the FOS concentration and PT the pretreatment of the apple slices.

The blanching was more efficient than the acidification for water loss and there was interaction between the temperature and concentration indicating that the variables should not be treated separately. 
An increase in the solution concentration and temperature favored water loss from the product because of the greater osmotic pressure gradient in the product/solution interface (Ferrari et al. 2005, Rastogi et al. 2004).

Figures $5 \mathrm{~A}$ and $5 \mathrm{~B}$ show the solid gain of the apple slices after osmotic dehydration, submitted to the acidification and blanching pretreatments, respectively.

For the solid gain, the model fitted the

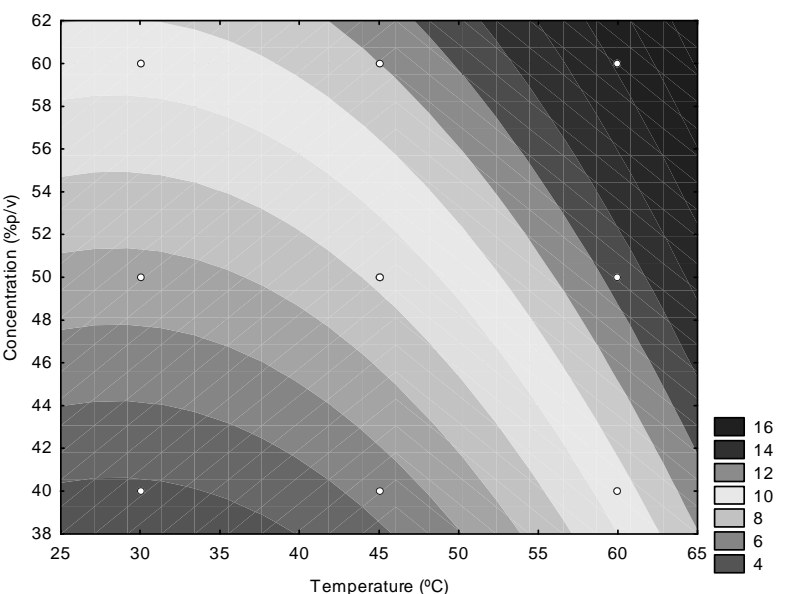

(A) experimental data well, with $\mathrm{R}^{2}=0.92$ and is represented by equation 8 .

$$
\begin{aligned}
& G S=11.1+1.5 \cdot T-0.6 \cdot T^{2}+1.26 \cdot C+0.7 \cdot P T \\
& +0.8 \cdot T \cdot C \\
& \mathrm{R}^{2}=0.92,
\end{aligned}
$$

where GS is the solid gain (\%), T the dehydration temperature, $\mathrm{C}$ the FOS concentration and PT is the pretreatment.

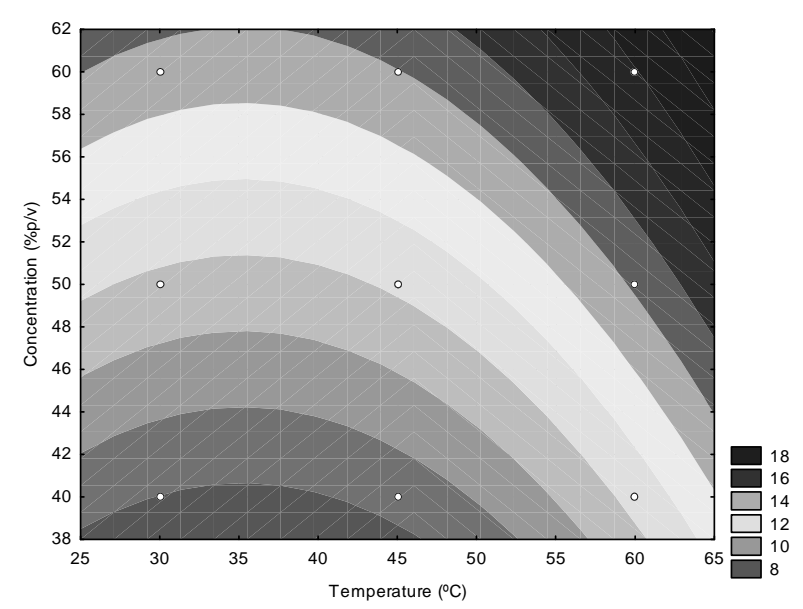

(B)

Figure 4 - Walter loss in osmotically dehydrated apple slices in the acidification (A) and blanching (B) pretreatments in function of temperature and fructo-oligosaccharides concentration.
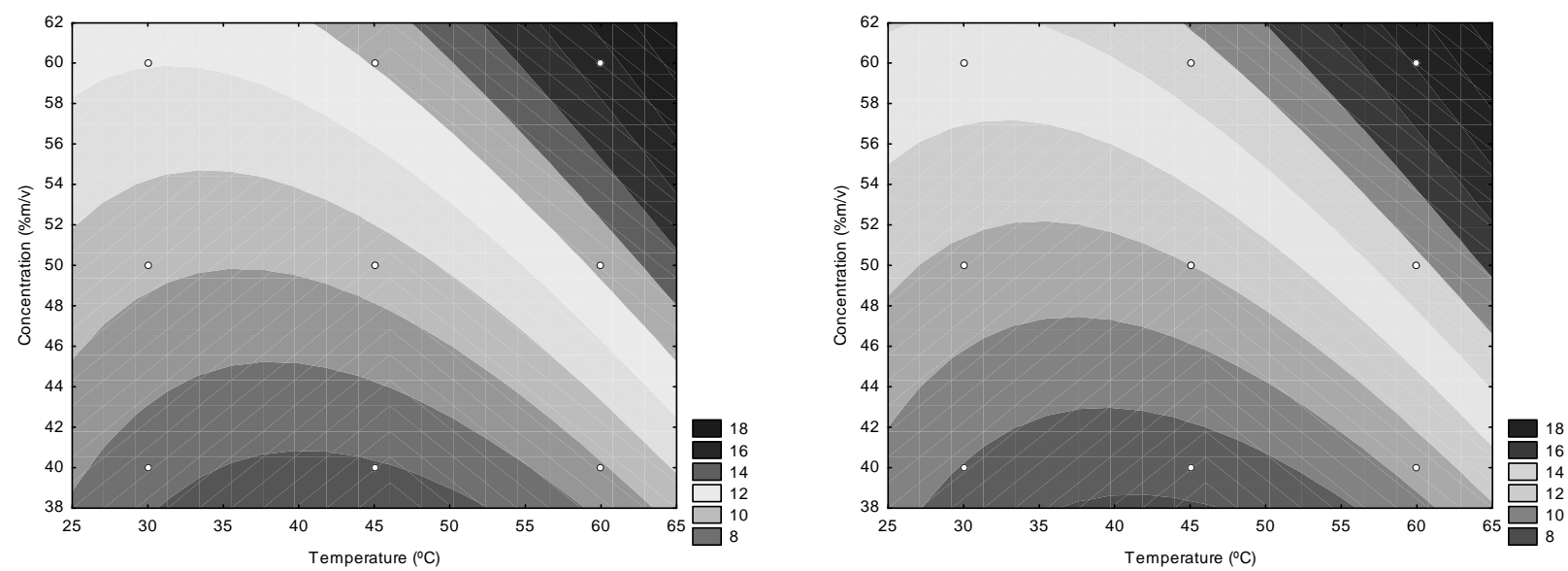

Figure 5 - Solid gain of the osmotically dehydrated apple slices in the acidification (A) and blanching (B) pretreatments in function of temperature and fructo-oligosaccharide concentration.

According to Matusek et al. (2008), who compared sucrose and FOS diffusion, and by Ferrari et al. (2005), who used maltose as osmotic agent, osmotic agents with greater molecular weight have a lower diffusion coefficient.
Dermesonlouoglou et al. (2008) studied osmotically dehydrated cucumber pretreated osmotically with fructo-oligosaccharides and high DE malt dextrin and then frozen. The accentuated effect of greater temperatures and osmotic solution 
concentrations on the increase in water loss and solid gains was in part due to the decrease in the solution viscosity that resulted in high water and solute diffusion rates. The moisture content and quantity of soluble solids were used as control variables for fructo-oligosaccharide incorporation in the apple slices by the osmotic process.

The pretreatments were chosen by joint optimization using the soluble solid content responses and the luminosity parameter ( $\left.\mathrm{L}^{*}\right)$.

Figure 6 showed the luminosity and soluble solid

content optimization, where the two variables chosen were maximized. The same response was found if the optimization was carried out by
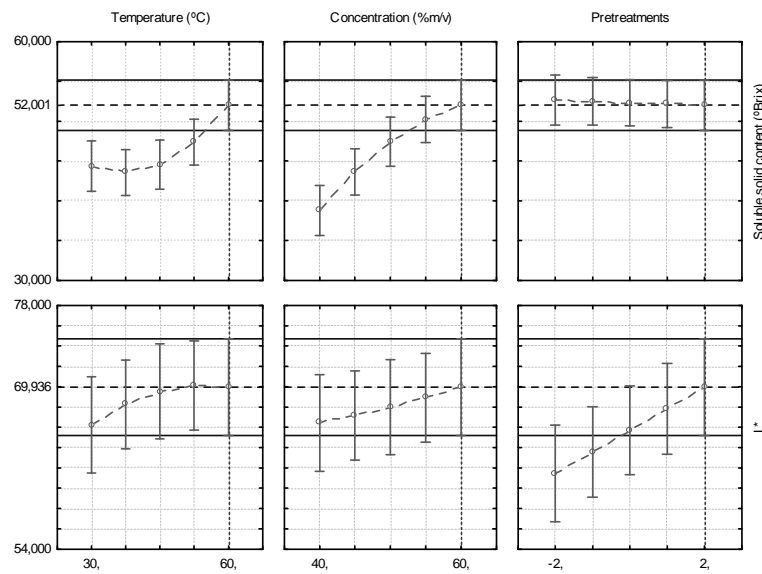

(A) maximizing the $\mathrm{L}^{*}$ parameter and minimizing the moisture content.

The optimum response for the soluble solid content was $52{ }^{\circ}$ Brix and $69 \mathrm{~L}^{*}$, using the highest concentration and temperature level $(60 \% \mathrm{~m} / \mathrm{v}$ and $60^{\circ} \mathrm{C}$, respectively) and acidification as pretreatment. It was observed that the same levels of the variables studied could be used to minimize the moisture content and maximize the luminosity parameter ( $43 \%$ and 69 , respectively). Thus, in the experimental design, the acidification pretreatment was fixed because it presented the best response in this combination.
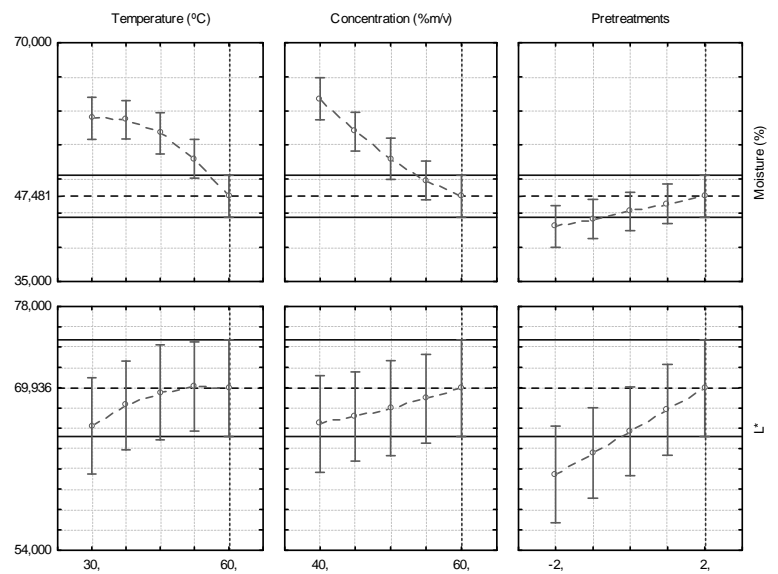

(B)

Figure 6 - Optimization of the soluble solids content and luminosity (A) and moisture content and luminosity in the osmotic dehydration process (B).

The independent variables temperature and osmotic solution concentration were studied in the acidification. An equation was modeled for the moisture variable, with $\mathrm{R}^{2}=0.98$ that showed good fit of the model to the experimental results (equation 9):

$$
\begin{aligned}
& \text { Moisture }=60,4-7,5 . T+1,5 T^{2}-8,6 . C \\
& -2,0 . T . C
\end{aligned}
$$

The superficial response graph of the apple moisture content as function of the FOS concentration and osmotic dehydration solution temperature is shown in Figure 7. The effect of temperature and FOS concentration on moisture was negative, that is, when these variables increased, moisture decreased and the effect of the concentration was greater than that of temperature.
The effect of temperature and FOS concentration were positive on the soluble solids content (Fig. 8 ). The maximum quantity of soluble solids was reached when the temperature was close to the upper limit of the design.

In this case, after choosing the acidification pretreatment, two treatments that involved the previously mentioned combinations were chosen for the final processing (drying) of the osmotically dehydrated apple slices. The treatments were $\mathrm{T} 4$ $\left(45^{\circ} \mathrm{C}\right.$ and $\left.40 \% \mathrm{~m} / \mathrm{v}\right)$ and $\mathrm{T} 7\left(60^{\circ} \mathrm{C}\right.$ and $\left.40 \% \mathrm{~m} / \mathrm{v}\right)$ that met the values of maximum quantities of daily FOS intake, that is $30 \mathrm{~g}$ fiber (whereas the initial solid soluble content is 13), according to the Brazilian legislation (Brazil 2002) considering $100 \mathrm{~g}$ product. 


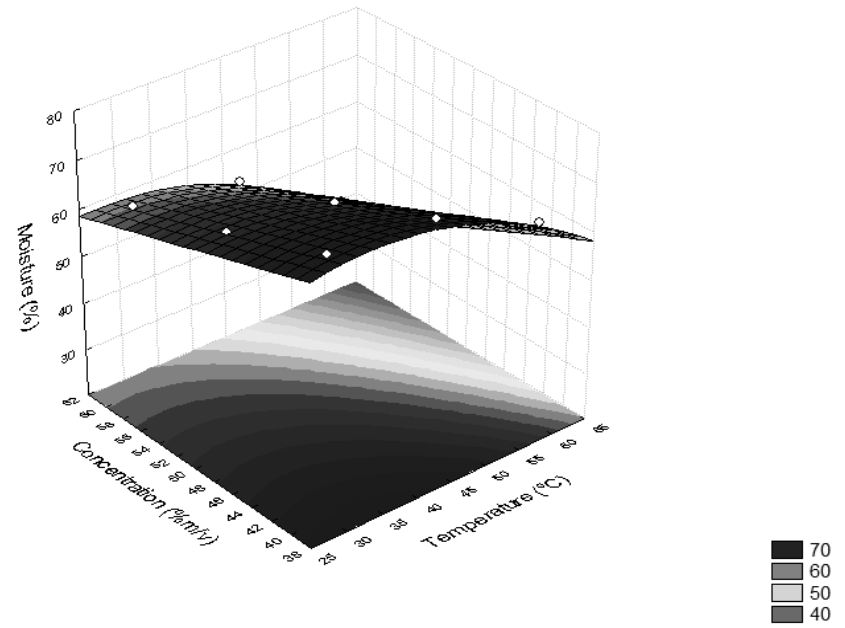

Figure 7 - Moisture content of osmotically dehydrated apple slices as function of FOS concentration and temperature.

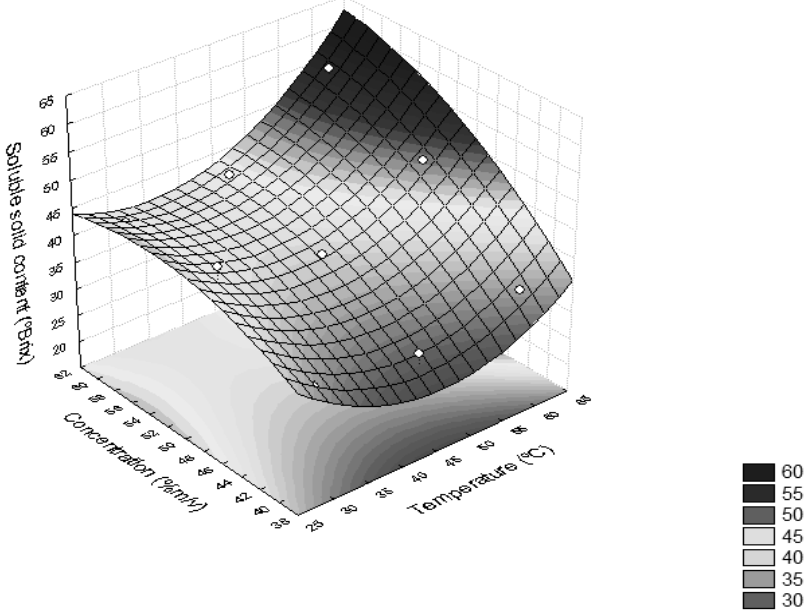

Figure 8 - Soluble solids content of osmotically dehydrated apple slices as function of the FOS concentration and temperature.

\section{CONCLUSION}

The acidification with $1 \%$ citric acid for 15 minutes was efficient in inhibiting the enzymatic browning in the slices of Fuji apples (Malus domestica) and did not interfere in the incorporation of fructo-oligosaccharides for osmotic dehydration. Osmotic dehydration of apple slices in the solution containing $30 \%(\mathrm{~m} / \mathrm{v})$ FOS at $50^{\circ} \mathrm{C}$ or $60 \%(\mathrm{~m} / \mathrm{v})$ at $40^{\circ} \mathrm{C}$ guaranteed a product within the legal parameters regarding the FOS content and the allegation of being a potentially functional product.

\section{REFERENCES}

Abud-Archila M, Várquez-Mandujano DG, RuizCabrera MA, Grajales-Lagunes A, Moscosa-Santillán M, Ventura-Canseco LMC, et al. Optimization of osmotic dehydration of yam bean (Pachyihizus erosus) using an orthogonal experimental desing. Food Eng. 2008; 84: 413-419.

Araújo JMA. Química de Alimentos: teoria e prática. 3nd ed. Viçosa: UFV; 2004.

A.O.A.C. - ASSOCIATION OF OFFICIAL AGRICULTURAL CHEMISTS. Official methods of analysis. 15nd ed. Washington; 1994.

Borin I, Frascareli EC, Mauro MA, Kimura M. Efeito do pré-tratamento osmótico com sacarose e cloreto de sódio sobre a secagem convectiva de abóbora. Ciên Tecnol Aliment. 2008; 28 (1): 39-50. 
BRASIL. ANVISA. AGÊNCIA NACIONAL DE VIGILÂNCIA SANITÁRIA. RDC $\mathrm{n}^{\circ} \quad 02.2002$ January 7. [cited 2009 March 23]. Available from: http://www.anvisa.gov.br/alimentos/comissoes/tecno _lista_alega.htm\#

Buchweitz, PR. Avaliação da Pré-Secagem de Kiwi (Actinidia deliciosa) complementada por processos convencionais [PhD Thesis]. Campinas, Brasil: Universidade Estadual de Campinas, Campinas, 2005.

Búrigo T, Fagundes RLM, Trindade EBSM, Vasconcelos HCFF. Efeito bifidogênico do frutooligossacarídeo na microbiota intestinal de pacientes com neoplasia hematológica. Rev Nutr. 2007; 20: 491-497.

Carnelossi MAG, Yaguiu P, Reinoso ACL, Almeida GRO, Lira ML, Silva FG, Jalali VRR. Determinação das etapas do processamento mínimo de quiabo. Hortic Bras. 2005; 23 (4): 970-975.

Cetnarski Filho R, Carvalho RIN, Martin VC. Caracterização da Maça Brasileira Comercializada em Curitiba e Região Metropolitana. Rev Acad, Ciênc Agrár Ambient. 2008; 6 (1): 21-27.

Chutintrasri B, Noomhorm A. Thermal inactivation of polyphenoloxidase in pineapple puree. Lebensm Wiss Technol. 2006; 39: 492-495.

Córdova, KRV. Desidratação osmótica e secagem convectiva de maça Fuji comercial e industrial [Dissertation]. Curitiba, Brasil: Universidade Federal de Curitiba, 2006.

Demczuk Junior B, Fachin DT, Ribani R H, Freitas RJS. Degradação da cor e do ácido ascórbico na desidratação osmótica de kiwi. B do Ceppa. 2008; 26: 229-238.

Dermesonlouoglou EK, Pourgouri S, Taoukis OS. Kinetic study of the effect of the osmotic dehydration pre-treatment to the shelf life of frozen cucumber. Innovative Food Sci. Emerg. Technol. 2008; 9: 542549.

Dionello RG, Berbert PA, Molina MAB, Viana AP, Carlesso VO, Queiroz VA. Desidratação por imersãoimpregnação de abacaxi em soluções de sacarose e em xarope de açúcar invertido. Ciên Tecnol Aliment. 2007; 27: 701-709.

Drogoudi PD, Pantelidis G. Effects of position on canopy and harvest time on fruit physico-chemical and antioxidant properties in different apple cultivars. Sci Hortic - Amsterdam. 2011; 129: 752-760.

Elias NF, Berbert PA, Molina MAB, Viana AP, Dionello RG, Queiroz VAV. Avaliação nutricional e sensorial de caqui cv. Fuyu submetida à desidratação osmótica e secagem por convecção. Ciênc Tecnol Aliment. 2008; 28: 322-328.

Escobar MP, Galindo FG, Wadsö L, Nájera JR, Sjöholm I. Effect of long-term storage and blanching pre-treatments on the osmotic dehydration kinetics of carrots (Daucus carota L. cv. Nerac). Food Eng. 2007; 81: 313-317.
Feliciano RP, Antunes C, Ramos A, Serra AT, Figueira ME, Duarte CMM, et al. Characterization of traditional and exotic apple varieties from Portugal. Part 1 - Nutritional, phytochemical and sensory evaluation. J Functional Foods. 2010; 2, 35 - 45.

Fernandes FAN, Rodrigues S, Gaspareto OCP, Oliveira EL. Optimization of osmotic dehydration of papaya follows by air- drying. Food Res Int. 2006; 39: 492498.

Ferrari, CC, Rodrigues LK, Tonon, RV, Hubinger, MD. Cinética de transferência de massa de melão desidratado osmoticamente em soluções de sacarose e maltose. Ciên Tecnol Aliment. 2005; 25 (3): 564-570.

Haminiuk CWI, Oliveira CRG, Baggio ECR, Masson ML. Efeito de pré-tratamentos no escurecimento das cultivares de maça Fuji e Gala após o congelamento. Ciênc Agrotec. 2005; 29: 1029-1033.

Hauly, COM, Moscatto JA. Inulina e Oligofrutose: uma revisão sobre propriedades funcionais, efeito prebiótico e importância na indústria de alimentos. Semina: Tech Ex. 2002; 23: 105-118.

HUNTERLAB. CIE L*a*b* color scale: applications note. Virginia; 1996. [cited 2009 Abr. 10]. Available from: http://www.hunterlab.com/color_theory.php.

Kowalska H, Lenart A, Leszczyk D. The effect of blanching and freezing on osmotic dehydration of pumpkin. Food Eng. 2008; 86: 30-38.

Lerici CR, Pinnavaia G, Dalla Rosa M, Bartolucci L. Osmotic Dehydration of Fruit: Influence of Osmotic Agents on Drying Behavior and Product Quality. $J$ Food Sci. 1985; 50: 1217 - 1219.

Lewicki PP, Lukaszuk A. Effect of osmotic dewatering on rheological properties of apple subjected to convective drying. Food Eng. 2000; 45: 119-126.

Martinez ZMV, Whitaker JR. The biochemistry and control of enzymatic browning. Trends Food Sci Tech 1995; 6: 195-200.

Matusek A, Czukor B, Merész P. Comparison of sucrose and fructo-oligosaccharides as osmotic agents in apple. Innovative Food Sci. Emerg. Technol. 2008; 9: 365-373.

Moreno J, Chiralt A, Escriche I, Serra JA. Effect of blanching/osmotic dehydration combined methods on quality and stability of minimally processed strawberries. Food Res Int. 2000; 33: 609-616.

Mussatto SI, Mancilha IM. Non-digestible oligosaccharides: a review. Carbohyd Polym. 2007; 68: 587-597.

Ozdemir M, Ozen BF, Dock LL, Floros JD. Optimization of osmotic dehydration of diced green peppers by surface methodology. Food Sci TechnolLeb. 2008; 41: 2044-2050.

Paes SS, Stringari GB, Laurindo JB. Effect of vacuum impregnation temperature on the mechanical properties and osmotic dehydration parameters of apples. Braz Arch Biol Technol. 2008; 51 (4): 799806. 
Passos LML, Park YK. Fruto-oligossacarídeos: implicações na saúde humana e utilização em alimentos. Cienc Rural. 2003; 33: 385-390.

Pereira LM, Rodrigues ACC, Sarantópoulos CIGL, Junqueira VCA, Cardello HMAB, Hubinger MD. Vida-de-prateleira de goiabas minimamente processadas acondicionadas em embalagens sob atmosfera modificada. Ciênc. Tecnol. Aliment. 2003; 23: 427-433.

Qiang X, Young Lie C, Qian Bing W. Health benefit application of functional oligosaccharides. Carbohyd Polym. 2009; 77, 435-441.

Raoult-Wack AL. Recent advances in the osmotic dehydration of foods. Trends Food Sci Tech. 1994; 5: 255-260.

Rastogi NK, Raghavarao KSMS, Niranjan K, Knorr D. Recent developments in osmotic dehydration: methods to enhance mass transfer. Trends Food Sci Tech. 2002; 13: 48-59.

Rastogi NK, Raghavarao KSMS. Mass transfer during osmotic dehydration of pineapple considering Fickian diffusion in cubical configuration. Lebensm Wiss Technol. 2004; 37, 43-47.

Salas NA, Molina-Corral FJ, González-Aguilarb GA, Oteroa A, Sepulveda DR, Olivasa GI. Volatile production by 'Golden Delicious' apples is affected by preharvest application of aminoethoxyvinylglycine. Sci Hortic - Amsterdam. 2011; 130: 436-444.

Sapers GM. Browning of food: Control by sulfites, antioxidants and other means. Food TechnolChicago. 1993; 47: 75-84.

Sharma SK, Mulvany SJ, Rizvi, SH. Food process engineering: theory and laboratory experiments. New York: Wiley Interscience; 2000.
Sousa PHM, Maia GA, Sousa Filho MSM, Figueiredo RW, Nassu RT, Sousa Neto MA. Influência da concentração e da proporção fruta: xarope na desidratação osmótica de bananas processadas. Ciênc Tecnol Aliment. 2003; 23 (Supl): 126-130.

StatSoft, Inc. (2005). STATISTICA (data analysis software system), version 7.1. Available from: http://www.statsoft.com.

Uddin MB, Ainsworth P, Ibanoglu S. Evaluation of mass exchange during osmotic dehydration of carrots using response surface methodology. Food Eng. 2004; 65: 473-477.

Valente PPSS. Desidratação Osmótica e Secagem de Abacaxi (Ananás Comosus (L.) Merril), variedade pérola [Dissertation]. Campinas, Brasil: Universidade Estadual de Campinas; 2007.

Vega-Gálvez A, Palacios M, Boglio F, Pássaro C, Jeréz C, Lemus-Mondaca R. Deshidratión osmótica de La papaya chilena (Vasconcellea pubescens) e influencia de la temperatura y concentración de la solución sobre la cinética de transferencia de materia. Ciênc. Tecnol. Aliment. 2007; 27: 470-477.

Received: May 09, 2011; Revised: October 28, 2011; Accepted: February 14, 2012. 